\title{
RAILWAY CORRIDOR AS A FUNCTIONAL SUBSYSTEM FOR REBALANCING SOCIALLY AND ENVIRONMENTALLY METROPOLITAN AREAS
}

\author{
JOAN MORENO SANZ \\ Universitat Politècnica de Catalunya, Spain
}

\begin{abstract}
The way we move around a territory is linked to the way we occupy it. In this sense, integrated spatial and transport planning is useful to build relations between land-use patterns and mobility flows in line with principles of sustainable urban development such as spatial cohesion, social inclusion, environmental quality and economic competitiveness. The main goal of this paper is to assess the strengths and weaknesses of railway corridors as Metropolitan functional systems according to public transport networks in compact and mixed land-use urban environments based on TOD models. The initial hypothesis is that railway corridors could become functional subsystems at the metropolitan level based on specialized activities which combine the local and global, public and private, natural and manufactured, as well as social inclusion and economic growth. Methodologically, the paper suggests a structural prospective analysis of spatial politics implemented in metropolitan railway districts as transportation nodes and urban centralities based on quantitative and qualitative indicators. Under this method, the spatial area around each train station $(800 \mathrm{~m})$ is analysed from three perspectives: connectivity to local networks, built and planned land-use patterns, and governance and public functions assigned with regard to infrastructural networks and spatial planning. The research project analyses the capacity for transforming railway districts into metropolitan hubs, where transportation efficiency and urban development take place at the regional level as a coordinated functional subsystem. The study cases are the Stedenbaan and the Sleutelprojecten Programmes carried out in the Randstad. These programmes suggest an integrated spatial planning between public transportation networks and urban centres. Specialised and coordinated urban development oriented to public transport could contribute to economic competitiveness, inclusive mobility, and environmental infrastructure at the metropolitan level.
\end{abstract}

Keywords: public transport network, metropolitan areas, Stedenbaan Programme, Randstad-Holland.

\section{INTRODUCTION}

At the beginning of the 20th century, the Modern Movement established circulation as one of the four basic functions of the human being, along with living, working and leisure [1]. To date, these activities have been developed in an integrated way in traditional urban centres. However, technological advances in transportation and the popularization of certain modes, particularly private vehicles, increased urban mobility and favored the dispersion of activities throughout the territory. Simultaneously with the dynamics of urban dispersion and functional specialization, a process of specialization-segregation of the transport network has taken place. Citizens live, work and enjoy leisure in different spaces, and consequently, the need for mobility between these spaces increases. On the other hand, the infrastructure networks that support the movement between centres of activity are designed in accordance with principles of efficiency, safety and comfort, so that finally, the logic of transport prevails in the territory.

The urban centrality geographical was considered a form of mass expression, with increases in demographic density, circulation intensity, activity volume, etc. The development of networks and their exposure to urban flows has turned the transport infrastructure into a space of new centrality at the metropolitan scale, especially favored by 
the development of new interurban highways. In this sense, urban development pursues the opportunity of developing from the transport network. However, policies for the integration of mobility and land uses, based on compact and functionally mixed urban development models, contribute to improving the efficiency of the transport network and preserving land for future needs. Currently, urban planning policies based on the interaction between mobility and land uses prioritize public transport networks because they can absorb a high demand from users in conditions of safety and comfort, in addition to structuring the territory.

The main objective of this article is to assess the role of railway corridors as functional subsystems in metropolitan territories. From a methodological point of view, spatial planning policies implemented in the railway districts are analyzed based on quantitative and qualitative criteria. Two spatial planning programmes, carried out in the Randstad - the metropolis of the Netherlands that includes the province of Zuid-Holland - Stedenbaan "Citiesway" and Sleutelprojecten "Keyprojects", have been chosen for this case study. The aforementioned programmes aim to promote urban regeneration and development of the Dutch railway districts through urban densification strategies, activities diversification, and public transport service efficiency improvement. In short, these policies are committed to a polycentric, compact, coordinated and well-connected urban network that takes the public transport network as a development guideline.

\section{COMPACT CITY MODEL AND TRANSIT ORIENTED DEVELOPMENT}

The compact, dense and accessible city is one of the most efficient forms of spatial planning from an environmental and social point of view [2]. In addition, the compact city is one of the models promoted by the United Nations in the Sustainable Development Goals [3] because they combine density, mixed land uses, and favor the use of public transport over the private vehicle. At the opposite extreme, their low density, land functional specialization, spatial fragmentation of the territory, and low accessibility, characterizes dispersed urban planning models. Furthermore, these dispersed urban models imply a high consumption of land and a high dependence on less inclusive private means of transportation. Therefore, there is an unquestionable relationship between the territorial organization model (compactdispersed) and the means of transport chosen preferably by citizens, in addition to the level of access for vulnerable populations and the impact of mobility on the environment [4].

The relationship between mobility and land uses (Fig. 1) responds to a feedback cycle in which the emergence of new urban centres [5] in the territory can trigger increases in network traffic, and vice versa [6]. This relationship of reciprocal development between mobility and activity can lead to situations of extreme congestion or collapse of the urban and transport network. One of the aspects that determines mobility planning in the territory is the urban density served by the transport network. On the one hand, the compactness and urban mix entail the reduction of the travel distance and favors the active mobility. On the other hand, greater user demand guarantees the economic viability of a transport system, especially if this system connects dense and diverse centres. The relationship of the spatial dimension and the intensity of activity between proximate centres establishes an urban hierarchical order at a territorial scale [7]. The connection of these nodes through linear transport structures contributes to the formation of nodal corridors along the lines of the Transit Oriented Development (TOD) models [8].

\subsection{Transit Oriented Development (TOD)}

The TOD model is based on the development of a system of urban communities of limited extension, and organized around a transport axis, preferably public, on a regional scale [6]. 
The theoretical antecedents of the TOD model emerge during the European post-war period in the UK and Scandinavia. The housing emergency and resource scarcity encouraged the construction of new peripheral and self-sufficient cities like the model of the English New Town or the Swedish railway districts like Vällingby. The creation of these new urban settlements on the existing public transport network allowed optimizing service supply networks and reduced real estate pressure on the centres of large capitals. In the 1980s in North America, the New Urbanism movement developed the concept of Transit Oriented Development focused on creating dense, functionally diverse and socially heterogeneous residential neighborhoods, organized according to human scale and therefore walking distances.

The success of the settlements ordered according to the TOD model depends on the effective coordination between public transport networks, both motorised and non-motorised. A hierarchical urban structure around transport nodes, with established densities and growth limits, is advanced at the territorial scale. The urban consolidation of these nodal corridors configures a regional structure that allows reserving land for future needs. In order to maximize access to centres and minimize the impact of traffic on the central artery, the minimum distance between nodes is set at one mile. Once at the access, a secondary network distributes the circulation through the neighborhoods at a maximum distance of 10 minutes from the central transport axis. Urban densities are adapted to both the capacity of the roads and the nature of the traffic. In this sense, an efficient and comfortable public transport system can become a competitive alternative to the use of the private vehicle.
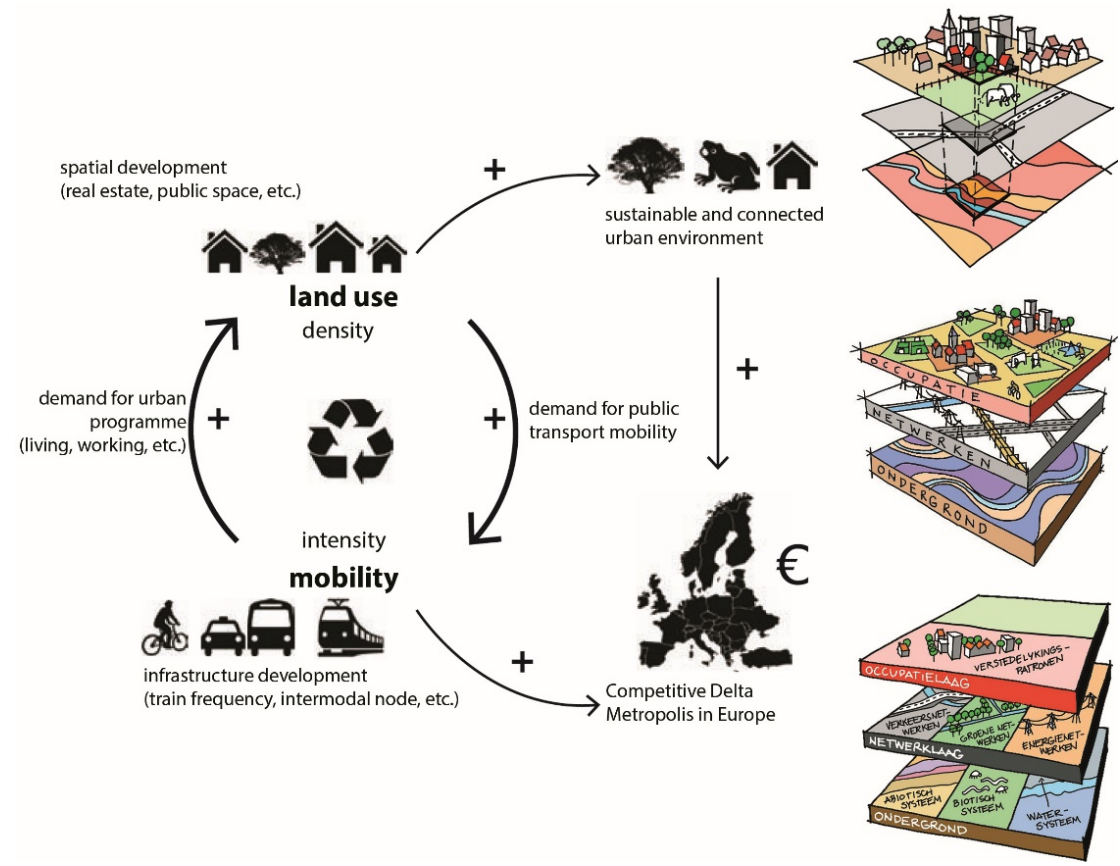

Figure 1: The transport-land-use feedback cycle [9].

As for the internal organization of TOD districts, the TOD management principles are based on the concepts of urban compactness and functional mix. Average urban densities 
are set at 44 dwelling units per hectare. This indicator ranges from $30 \mathrm{du} / \mathrm{ha}$, for neighborhoods with predominance of single-family dwellings, to $62 \mathrm{du} / \mathrm{ha}$, for neighborhoods with predominance of apartment blocks [6]. In addition to urban density, the other basic design parameter is the functional mix. In the centre of TOD neighborhoods, the indicators establish a percentage of 5-15\% for public facilities and services, $30-70 \%$ for productive sectors, and $20-60 \%$ for residential uses. In this way, the character of an urban centre in which non-residential uses predominate is reinforced. The indicators of functional mixture in the periphery are appreciably different since the portion of land destined for housing ranges from $50-80 \%$ and for the productive sector from $10-40 \%$ [8].

In summary, the TOD model is based on the principles of compact, walkable, mixed and accessible city through inclusive transportation systems. From the point of view of urban mobility, the physical proximity between activity areas such as residential, commercial or public facilities, favors travel by non-motorised means of transport such as cycling or walking (active mobility), in conditions of sufficient urban density. However, an urban node ordered under these principles is meaningless if it is not integrated into a regional scale structure. The territorial scale of the TOD system makes possible to streamline the management of land and transport networks. The implementation of a management model that simultaneously develops the urban and transport networks prevents the appearance of conflicts with pre-existing urban systems. On the other hand, the TOD model is not advanced exclusively as the solution to a spatial problem but is also a proposal of social, economic and technical nature [10].

\section{THE RANDSTAD AS A CASE STUDY}

\subsection{The Randstad as a territorial unit}

According to tradition, the name Randstad to designate the conurbation of the Dutch delta is attributed to KLM co-founder Albert Plesman in the late 1920s. The Randstad, literally Edge City, was made up of a chain of urban centres shaped like a horseshoe around a central agricultural area: the Groene Hart [11]. Despite the social acceptance of the concept, the Randstad, as a spatial figure, was not recognized by Dutch urban planning until the 1950s. The first documents that collected the term were the Ontwikkeling van het westen des Lands report (1958) [12] and the First Planning Memorandum of the Netherlands (1960) [13]. However, the spatial recognition of the Randstad as a geographical and functional unit did not imply an effective recognition as an administrative entity. The Randstad is currently fragmented between the provinces of Noord-Holland, Zuid-Holland, Utrecht and Flevoland. The metropolis does not have its own legislative capacity and its territorial planning is in the hands of the local and provincial administrations

One of the particularities of the Randstad compared to other nearby conurbations such as Paris or London is the specialized polycentric nature of its urban network. Activities of an administrative, cultural nature, etc., are not located in a single centre in the case of the Randstad but are distributed throughout the metropolitan territory. The urban network is hierarchically commanded by the four main capitals: Amsterdam, Rotterdam, The Hague and Utrecht, and then there is a second range of cities with a population greater than 100,000 inhabitants such as Leiden, Delft, Haarlem or Dordrecht (Fig. 2). In addition, the main gateways to the country are located in the metropolis: Schiphol International Airport and the Port of Rotterdam. The approximate extension of the metropolis is $6,000 \mathrm{~km}^{2}$. With a population of over seven million inhabitants, $43 \%$ of the population of the Netherlands, it 
is one of the most densely populated urban regions in Europe with 1,500 inhabitants per $\mathrm{km}^{2}$ [14].

In relation to transport networks, the Dutch primary network has a total length of $132,397 \mathrm{~km}$ of which $2,350 \mathrm{~km}$ are expressways [15]. One of the structural problems of the Dutch road network is the lack of connectivity at the local level, which is why traffic is highly dependent on motorways. In the latest decades, the Dutch government's mobility policies have been aimed more at increasing network capacity than at building new interurban connection hubs. On the other hand, the interurban rail network has a total length of $2,972 \mathrm{~km}$, a daily flow of 1.1 million daily passengers and an average of 5,000 scheduled services per day. The Dutch railway network is for the most part a mix of passengers and freight. Freight transport barely accounts for $2 \%$ of the total and the line with the highest volume is the Betuweroute between the Port of Rotterdam and the border with Germany [14].

With the goal of improving the functionality of the Randstad at the beginning of the 20th century, two urban subsystems or "stedelijke gebieden" were established, the Noordvleugel in the northern sector, and the Zuidvleugel in the southern one. The Zuivleugel, literally the southern wing, corresponds to the administrative province of Zuid-Holland, and has a population of 3.3 million people, of which 2.6 million reside in the Rotterdam-The Hague metropolitan area [14]. Therefore, despite the markedly polycentric nature of the region with university centres of international relevance such as Delft or Leiden, practically a third of the population is concentrated in the two capitals. From an administrative point of view, the Zuidvleugel does not have a competency framework that allows it to approve spatial management plans, for this reason, any urban development plan at the regional level responds to the voluntary agreement between local administrations, coordinated by the provincial administration.

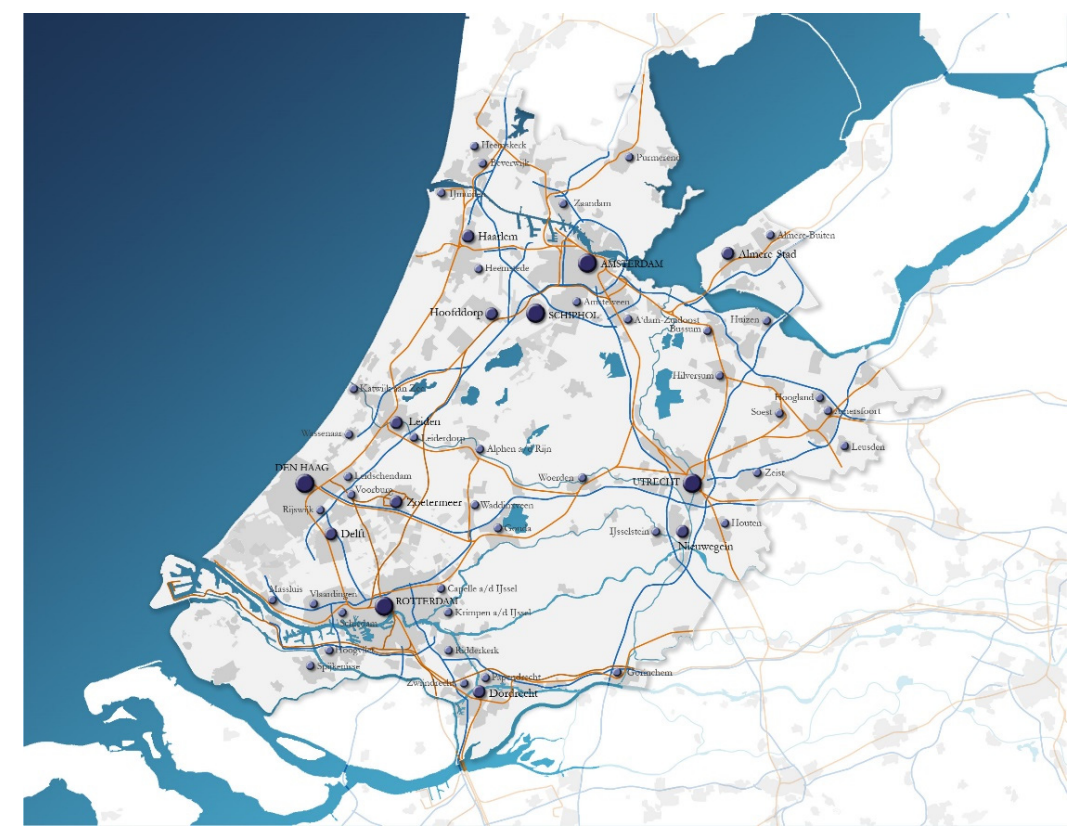

Figure 2: Urban network in the Randstad. (Source: Compiled by the author based on Moreno, [15].) 


\subsection{Urban policies in the Randstad}

Despite the development containment policies promoted by the Government of the Netherlands since the end of World War II, urban sprawl processes significantly altered the structure of the Dutch cities ring. In the 1960s, "centralized decentralization" [16] policies were implemented allowing limited development of new urban settlements on the periphery of the large capitals of the Randstad as satellite cities, such as Almere as for Amsterdam or Zoetermeer as for The Hague [17]. The construction of these new low-density residential settlements led to an increase in the use of private vehicles and, consequently, congestion on the regional road network. In this context, the public transport system in general, and the rail network in particular, proved to be little competition against the private vehicle due to the low coverage and efficiency of the service in suburban stations. The railway network that had guided the urban development of the Randstad during the first half of the 20th century gave way to the motorway network during economic developmentalism.

Beginning in the 1970s, new environmental awareness and energy crises forced a paradigm shift in the relationship between the urban and transport networks. The Dutch government promoted a program of integrated planning measures for mobility and urban activity that are included in the IV Memorandum of national spatial planning (1988) [18], in particular in the specific annex on housing known as VINEX (1991) [19]. The VINEX plan was promoted by the Ministry of Housing, Spatial Planning and Environment (VROM) and involved the construction of one million houses over a period of 15 years. The principles of locating new urban settlements, both residential and productive, were based on ABC policies. These spatial planning policies offered incentives for the implementation of new districts in proximity to existing urban centres or public transport stations, in addition to promoting active mobility in their local network.

At the end of the 1990s, the urban planning departments of the four capitals of the Randstad signed a declaration promoting the urban development of the metropolis [19]. The objective was to reclaim the role of compact urban centres as the country's economic engines. The manifesto updates the concept of Randstad by that of Deltametropool and had an impact on improving international competitiveness and internal cohesion in the region. The document asserts the strengthening of transport networks, with special attention to the structuring role of railway stations in a densification model that places the compact city as a benchmark for urban development [20]. This type of plans and proposals, advanced the Dutch urban network as specialized polycentrism against the monocentric and highly hierarchical visions of other nearby conurbations [21]. These strategies required inter-municipal and multisectoral cooperation policies that would allow the development of the urban and transport network on a regional scale, in line with the TOD models.

\section{STEDENBAAN VS. SLEUTELPROJECTEN}

\subsection{Stedenbaan Program}

During the first decade of the 21st century, the Bestuurlijk Platform Zuidvleguel, an organism participated by the Zuid-Holland Province, the Haaglanden, Rijnland, Midden-Holland, Rotterdam and Drechtsteden regions, the municipalities of Rotterdam and The Hague, and the Dutch railway company NS, as well as supra-regional semi-public management companies; launches the Stedenbaan programme. The objective of the programme was the integrated planning of the public transport network (HOV) and territorial planning policies (RO) based on a double strategy. On the one hand, improving the efficiency of rail transport, 
and on the other hand, promoting coordinated management between municipalities of urban development in railway districts. In quantitative terms, the increase in frequency of passage and capacity of vehicles was proposed, as well as densification and intensification of urban activity, with a commitment to a compact urban model as a strategy to improve the efficiency of the transport network.

The Stedenbaan program is structured in three phases that comprise, first, the analysis of the flexibility of the area of action in quantitative terms, second, the evaluation of potential development, and third, evaluation of the fulfillment of each project to the objectives of regional development [21]. The first phase consists of the preparation of a catalog of actions with an execution horizon of one decade (2010-2020). The scope of action covers a radius of $1,200 \mathrm{~m}$ in the vicinity of the 47 railway stations in the region (34 existing and 13 potential). This meant a total area of 18,000 ha for the entire Zuidvleugel, equivalent to $25 \%$ of the urban land of the metropolis. If the average densities of the sector were taken into account, the urbanization of $20 \%$ of this land would mean the construction of 40,000 housing units and nearly one million square meters of productive uses [22].

The second phase consisted of drawing up an inventory of management strategies drawn up from the characteristics of the railway districts and public transport networks. Based on the quantitative and qualitative indicators collected in the first phase, a total of nine development strategies were established and assigned to each of the railway districts. These nine categories were (Fig. 3): Rural areas, with predominantly low-density urban and agricultural uses; villas, located on the periphery of rural areas; urban suburbs, as vacant spaces on the periphery of large capitals; future cities, compact and dense sectors with high accessibility by public transport; business centres, located in obsolete industrial estates; supraregional enclaves, areas in the nodes of the road network for the implementation of national facilities; centres in the Randstad, enclaves accessible at the regional level; creative cities, centers of innovation that combine residences and industry; and finally, urban centres, accessible spaces but with restricted use of the private vehicle [21].

The Stedenbaan programme proposed three possible functional specialization scenarios for the nodes of the railway corridor according to the categories mentioned above densification, connectivity and sustainability. The indicators for these scenarios were urban density growth, regional mobility improvement, and environmental quality preservation (Fig. 4). For the first, the increase in urban density at the transport nodes should guarantee the economic viability of the rail service. For the second, the improvement of the intermodal connection between regional and local networks should contribute to increasing the accessibility and the functional mix in the less dense railway districts. Finally, for the third, a scenario of sustainable development and building limits would allow preserving spaces of natural interest and promoting them as recreational spaces at the regional level.

The incorporation of the regional bus, metro, light rail and tram networks into the Stedenbaan programme, in addition to the Sprinter rail service, provided the opportunity for a reformulation of the project as Stedenbaan Plus [23]. One of the lines that was part of the programme was the Randstadrail light rail line between the cities of The Hague and Rotterdam via Zoetermeer (2006). Among the urban renewal projects carried out along the line, the Beatrixkwartier stood out. This economic district was located in the vicinity of The Hague CS and hosted the headquarters of some of the most important companies in the country such as TNT or ING, among others. Architectural quality was one of the distinctive aspects of this type of urban intervention, with the example of the Randstadrail viaduct section, built in the form of a tubular mesh, that has become one of the architectural icons of the Beatrixkwartier. It was estimated that $40 \%$ of the developable land in the region was located in the surroundings of this metropolitan network [23]. 

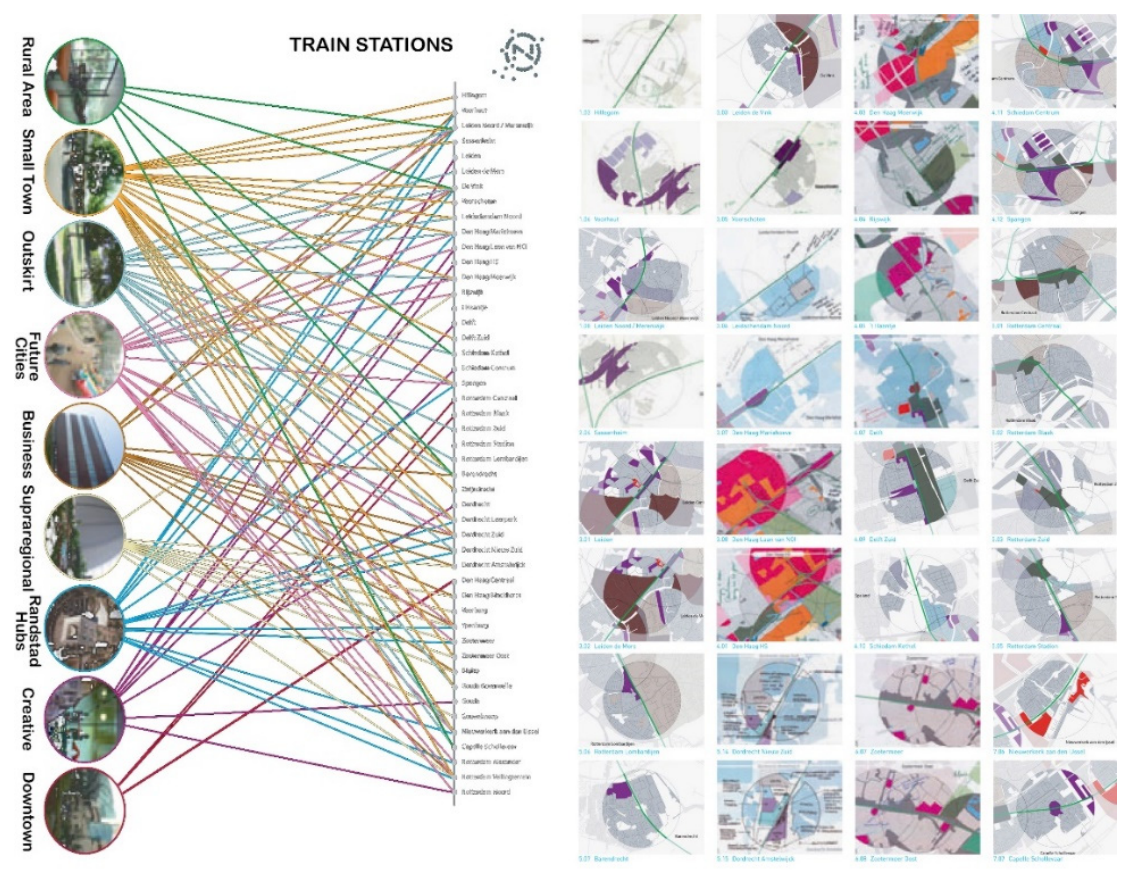

Figure 3: Urban strategies in the surroundings of the railway stations of the Zuidvleugel according to Stedenbaan model [21].

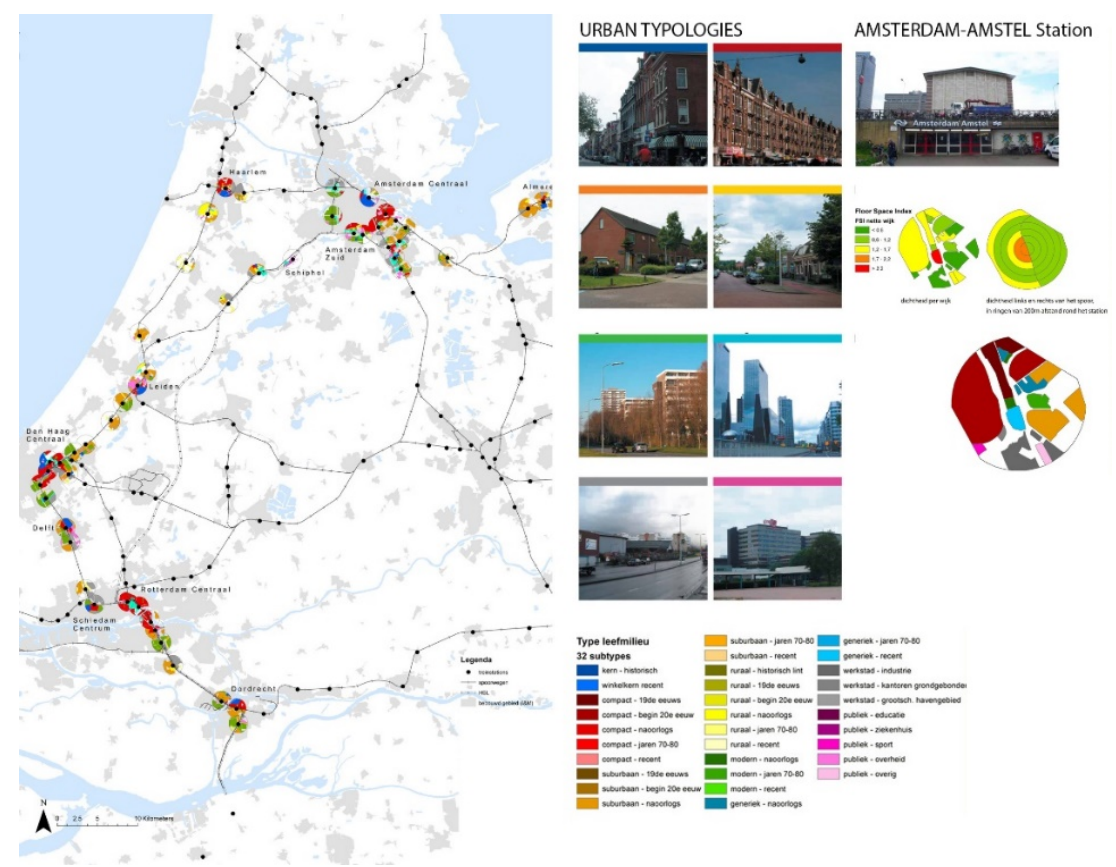

Figure 4: Stedenbaan Programme in the railway network of the Randstad [22]. 
The Stedenbaan project proposed the integrated planning of the public transport network and the urban network in a single coordinated system on a regional scale. Although the ultimate goal of the programme was to improve the regional and international economic competitiveness of the province of Zuid-Holland, the proposal focused on improving spatial and environmental quality in the surroundings of accesses to the transport network as well as enhancing the efficiency and comfort of the public transport network. The key to the urban (economic and social) development of these railway nodal corridors is based on the coordinated planning of actions, that is, on the establishment of a common development strategy at the regional level that encourages the transformation of the railway districts at the local level.

\subsection{New key projects (NSP)}

During the last quarter of the 20th century, the Dutch economy underwent a process of conversion from an industry-based model to the service and tertiary sector. The European convergence policies linked to globalization processes compromised the Randstad's competitiveness against other nearby metropolises such as London or Paris. In this context, the Dutch government promoted the improvement of the national urban network with the aim of attracting the headquarters of large multinational companies. The first actions focused on improving external connections or Mainports, that is, Schiphol Airport and the Port of Rotterdam. Later on, internal connections were modernized, especially between the large capitals of the Randstad. Furthermore, the relocation of industrial and logistical activities offered a unique opportunity for the renovation of large port infrastructures. The proximity of these projects to the traditional urban centres and their architectural quality or allowed to position well the large Dutch capitals at the international level [24].

In this context of economic paradigm change and compact city model promotion, the IV Memorandum (1988) was approved, which included the concept of Sleutelprojecten (SP). From an administrative point of view, the SP program was the first incursion of the national administration in an urban scale project and was part of the revision of the framework of relations between the public and private sector known as publiek-private samenwerking. One of the parameters for evaluating the success of the interventions was based on the ability to attract private investment and the areas real estate appreciation. In a first phase, the local and provincial public administrations together with private investors agreed on the selection of sites for the development of the renovation plans and proposed the nominations [22]. At the beginning, private initiatives were reluctant to compete in these types of projects, which is why the government developed four pilot projects that allowed for the establishment of agreed management and investment strategies between the public and private sectors.

The first generation of SP were focused on the regeneration of urban sectors left obsolete after economic reconversion. Port projects such as the Kop van Zuid in Rotterdam or the Oostelijk Havengebied in Amsterdam [24] belong to this stage. The second generation of Key Projects or Nieuwe Sleutelprojecten NSP focused on the renovation of the railway districts of the future HSL high-speed stations that included the four capitals of the Randstad. In both cases, these were large-scale projects with territorial repercussions. However, these projects were not limited to the renovation of port facilities and railway districts, but also included proposals such as the restoration of natural spaces for recreational purposes [25]. The project selection principles were: administrative transversality, ability to reconcile public and private interests, economic viability of the project, improvement of environmental quality, international repercussion of the proposal, and finally, reduction of dependence on the private vehicle [26]. 
After the first successful experience of SP, and in view of the large number of NSP candidates, the Dutch government feared that investments would become excessively fragmented in small-scale projects and would not have the international reach established the terms of the calls. For this reason, it was decided to prioritize the applications related to the Dutch high-speed rail network (HSL) that in the north-south direction connected Amsterdam CS, The Hague CS and Rotterdam CS with the Belgian border. Finally, the Dutch government selected six applications, the management of which was left to the local authorities. In practice, SPs are a set of urban projects of local scale, national economic interest and international connection that allow the Randstad to compete with other nearby polycentric conurbations such as the Rijn-Ruhr (Germany) or Vlaanderen (Belgium) [24].

\section{CONCLUSIONS}

Technological advances and the development of the transport network has favored the dispersion of urban activity throughout a territory. It should be noted that accessibility in itself does not guarantee the urban development of an area, but rather that adequate and comprehensive planning of transport activities and networks, based on the principles of density (quantitative) and diversity (qualitative), is necessary. The relationship between activity and mobility due to the feedback cycle after increase in mobility as a consequence of network improvement, can favor the dispersion of activity, but also, the intensification of uses in a location can lead to an increase in mobility demand. In this sense, policies for the integration of mobility and land uses, based on compact and functionally diverse urban planning models, contribute to the creation of a more efficient transport network and the preservation of land for future needs.

Currently, spatial planning policies based on the integration of mobility and land uses prioritize public transport networks, as in the Dutch case. Public transport can absorb a high passenger demand and offer adequate conditions of safety, comfort and inclusion. The configuration of an urban mobility model alternative to the use of private vehicles and dispersed planning, would imply the reduction of distances between activities, the urban environment densification and the improvement of public transport services by establishing a hierarchical order of connections. However, intervention in a transport node should not neglect understanding that it affects the system as a whole. Therefore, cooperation between competent administrations in the area of mobility and urban planning is necessary to promote the coordinated development of transport centers on a regional scale.

\section{ACKNOWLEDGEMENT}

Work produced with the support of a 2019 Leonardo Grant for Researchers and Cultural Creators, BBVA Foundation.

\section{REFERENCES}

[1] Le Corbusier, Principios de urbanismo: la carta de Atenas/Discurso preliminar de Juan Giradoux, Ariel quincenal: Barcelona, 1971.

[2] Herce, M., Sobre la movilidad en la ciudad: propuestas para recuperar un derecho ciudadano, Reverté: Barcelona, Estudios Universitarios de arquitectura, p. 187, 2009.

[3] UN, Habitat III Issue Papers 3 - Safer Cities. UN: New York, 2015.

[4] Bertolini, L. et al., Transit Oriented Development; Making It Happen, Ashgate: Farnham, 2009.

[5] Marseglia, G., Medaglia, C.M., Ortega, F.A. \& Mesa, J.A., Optimal alignments for designing urban transport systems: Application to Seville. Sustainability, 11(18), pp. 5058, 2019. https://doi.org/10.3390/su11185058. 
[6] Vereniging Deltametropool, Update-Sprintstad, Veriniging Deltametropool: Rotterdam, 3-4, 2010.

[7] Salingaros, N., Coward, L. \& West, B., Principles of Urban Structure, Techne: Amsterdam, 2005.

[8] Calthorpe, P. et al., The Next American Metropolis: Ecology, Community and the American Dream, Princeton architectural press: New York, 1993.

[9] Wegener, M. \& Fürst, F., Land-use transport interaction: state of the art, TRANSLAND (Deliverable 2a), 1999.

[10] Guy, S. \& Marvin, S., Models and Pathways; The Diversity of Sustainable Urban Futures. Achieving Sustainable Urban Form, E. and F.N. Spon: London, 2000.

[11] Duinen, L., Planning Imagery: The Emergence and Developments of New Planning Concepts in Dutch National Spatial Policy, Faculty of social and behavioural sciences (FMG): Amsterdam, 2004.

[12] Rijksdienst voor het Nationale Plan, De ontwikkeling van het westen des lands, Soil Survey Institute: The Hague, 1958.

[13] VROM, Ministerie can Volkshuisvesting, Ruimtelijke Ordening en Milieubeheer, Eerste Nota ruimtelijke ordening, Uitgeverij sdu: The Hague, 1960.

[14] CBS, Statistics Netherlands. https://www.cbs.nl/nl-nl/cijfers/detail/37296ned. Accessed on: 16 May 2020.

[15] Moreno, J., Urban Corners in Territory: An Integrated Land Use-Transport Model. The Randstad-Holland, Universitat Politècnica de Catalunya UPC: Barcelona, 2014.

[16] VROM, Ministerie can Volkshuisvesting, Ruimtelijke Ordening en Milieubeheer, Tweede Nota over de ruimtelijke ordening, Uitgeverij sdu: The Hague, 1960.

[17] Wagenaar, C., Town Planning in the Netherlands Since 1800: Responses to Enlightenment Ideas and Geopolitical Realities, 010 publishers: Rotterdam, 2011.

[18] VROM, Ministerie can Volkshuisvesting, Ruimtelijke Ordening en Milieubeheer, Vierde Nota ruimtelijke ordening, Uitgeverij sdu: The Hague, 1988-1990.

[19] VROM, Ministerie can Volkshuisvesting, Ruimtelijke Ordening en Milieubeheer, \& Ministerie van Verkeer en Waterstaat, Ambities voor de Deltametropool: eindrapportage interdepartamentaal project Deltametropool, VROM: The Hague, 2002.

[20] Boelens, L. \& Spit, T., Over de relationale setting van het compactestadbeleid. Design \& Politics, Compacte stad extended: agenda voor toekomstig beleid onderzoek en ontwerp, 4, pp. 106-123, 2011.

[21] Balz, V., Schrijnen, J. \& Bertolini, L., From Concept to Projects: Stedenbaan, The Netherlands. Transit Oriented Development: Making It Happen, Ashgate: London, pp. 75-90, 2009.

[22] Atelier Zuidvleugel, Space and Line: A Spatial Survey for Stedenbaan 2010-2020, The South Wing of the Randstad. Nova Terra Connected Cities, Instituut voor ruimtelijke ordening en Volkshuisvesting, NIROV: The Hague, pp. 11-16, 2007.

[23] MIES, Stedenbaan, Monitor Stedenbaan 2016, Stedenbaan: The Hague, 2016.

[24] Dings, M., Historisch perspectief 1900-2010. Ontwerk en politiek, 1, VROM: The Hague, pp. 11-158, 2009.

[25] VROM, Ministerie can Volkshuisvesting, Ruimtelijke Ordening en Milieubeheer, Rapportage 1993 over de voortgang van de Sleutelprojecten ruimtelijke inrichting, Rijksplanologische dienst: The Hague, 1994.

[26] Huisman, J. \& Linders, J., The nieuwe Sleutelprojectgen, op weg naar 2030, Spoorbeld door Burearu Spoorbouwmeester: The Hague, 2016. 